\title{
Rassegroepe se evaluering van kriteria by motorvoertuigaankope
}

\author{
P.J. du Plessis \\ Skool vir Bedryfsleiding, Universiteit van Suid-Afrika, Posbus 392, Pretoria, 0001
}

Ontvang 5 Mei 1987; Aanvaar 10 Junie 1987

\begin{abstract}
The objective of this study was to determine whether differences and/or similarities exist in the relative importance of evaluation criteria between the various race groups in South Africa when purchasing a motor vehicle. The sample consisted of 577 whites, 114 coloureds, 102 Asians and 109 blacks mainly from metropolitan areas. Variance analysis was applied to establish that there were 52 significant differences out of a total of 65 evaluation criteria with respect to the various race groups. Results showed that the biggest significant differences occurred between whites and blacks ( $66 \%$ of the evaluation criteria) and between whites and Asians ( $43 \%$ of the evaluation criteria).
\end{abstract}

Die doel van hierdie studie was om te bepaal of daar ooreenkomste en/of verskille bestaan tussen die verskillende rassegroepe in Suid-Afrika se evaluering van kriteria by die aankoop van 'n motorvoertuig. Die steekproef het bestaan uit 577 Blankes, 114 Kleurlinge, 102 Asiërs en 109 Swartes van hoofsaaklik metropolitaanse gebiede. Met behulp van variansie-ontleding is daar vasgestel dat daar beduidende verskille ten opsigte van 52 uit die 65 evalueringskriteria met betrekking tot die verskillende rassegroepe is. Die resultate het verder aangetoon dat die grootste verskille tussen Blankes en Swartes (by $66 \%$ van die evalueringskriteria) en tussen Blankes en Asiërs (by $43 \%$ van die evalueringskriteria) voorgekom het.

In die Suid-Afrikaanse motorvoertuigmark vertoon kopers 'n heterogene samestelling ten opsigte van ras, kultuur, geslag, ouderdom, inkomste, waardes, houdings en motiewe. Wat ras betref is daar' $n$ neiging dat die Blankeverbruikersmark se aandeel van geregistreerde passasiersmotorvoertuie 'n daling begin toon (Du Plessis, 1986:15). Daarenteen toon die Kleurling-, Asiëren Swartrassegroep 'n neiging van positiewe groei betreffende die aandeel in die totale mark van geregistreerde passasiersmotorvoertuie.

Blankes se aandeel in geregistreerde motorvoertuie in 1983 het 1,8 miljoen beloop; dié van Kleurlinge 151 000; Asiërs 131000 en dié van Swartes 241000 (Sentrale Statistiekdiens, 1984). 'n Vooruitskatting van Marks (in Marks \& Brown, 1981:582) dui daarop dat Blankes se aandeel in die totale geregistreerde motorvoertuie in die jaar 2000 ongeveer 3,2 miljoen sal wees. Wat Kleurlinge en Asiërs betref sal die besit gesamentlik 460000 wees en die van Swartes 1,7 miljoen. Daarbenewens voorspel Loubser (1985) dat die persentasiestyging in persoonlike besteebare inkomste vir die verskillende rassegroepe teen die jaar 2000 (1985 as basis) vir Blankes met 20,2\% sal styg; dié van Kleurlinge met $95,6 \%$; Asiërs met $133 \%$ en die Swartes s'n met $100,4 \%$.

Daar kan bespiegel word dat Blankes oorwegend die nuwemotor-mark se afset sal opneem (hoofsaaklik uit 'n vervangingsoogpunt) en dat die ander rassegroepe, veral Swartes, op die gebruiktemotor-mark aangewese sal wees. Hierdie vooruitskattings suggereer dat daar onder andere ' $n$ potensiële groei in die motorvoertuigbesit kan plaasvind. Dit is dus belangrik om betroubare inligting oor verbruikers en hulle gedrag ten opsigte van die aankoop van 'n motorvoertuig, te bekom.

\section{Agtergrond tot die studie}

By die aankoop van 'n motor is daar verskeie evalueringskriteria wat 'n koper in ag kan neem. Die hoofdoelstelling met hierdie studie was om die relatiewe belangrikheid van verskeie evalueringskriteria vir verbruikers (kopers) by die aankoop van 'n motor te bepaal. Meer spesifiek wou die outeur die hipotese ondersoek dat daar 'n verskil is wat betref die relatiewe belangrikheid wat verskeie rassegroepe aan evalueringskriteria heg by die aankoop van 'n motor.

Die studie was beperk tot aankope van passasiersmotorvoertuie vir private gebruik; het nuwe sowel as gebruikte motors ingesluit; was uitgevoer in hoofsaaklik metropolitaanse gebiede van die R.S.A.; het kopers van die Blanke-, Kleurling-, Swart- en Asiërrassegroep betrek.

\section{Kriteria by motoraankope aanwesig}

Verbruikersgedrag kan gedefinieer word as besluitnemingseenhede (individue sowel as gesinne) se gedragspatrone wat die besluitnemingsproses, vir die verkryging van behoeftebevredigende produkte, idees en dienste voorafgaan, bepaal en naloop (Du Plessis, 1986:39). Voorkeure en gewoontes van verbruikers word in die besluitnemingsproses gemanifesteer. Vyf fases in die verbruiker se besluitnemingsproses kan geïdentifiseer word, naamlik: probleembewuswording, inligtingsoeke, alternatiefevaluering, koopaksie en resultaat (Engel, Blackwell \& Miniard, 1986:35). Een van hierdie fases, te wete alternatiefevaluering, word verder verdeel in verskeie elemente soos in Figuur 1 aangetoon.

Uit Figuur 1 kan gesien word dat evalueringskriteria die grondslag van die verbruiker se opvattings vorm en dit, tesame met houdings en voornemens het 'n uitwerking op die alternatiefevaluering en aankoopfase. Kriteria wat in die evalueringsfase gebruik word, behels sowel fisiese produkattribute as subjektiewe faktore soos waardes en voordele wat die verbruiker in die aankoopproses as belangrik beskou.

Engel, et al. (1986:93) omskryf evalueringskriteria as produkgebaseerde voorstellings van onderliggende 


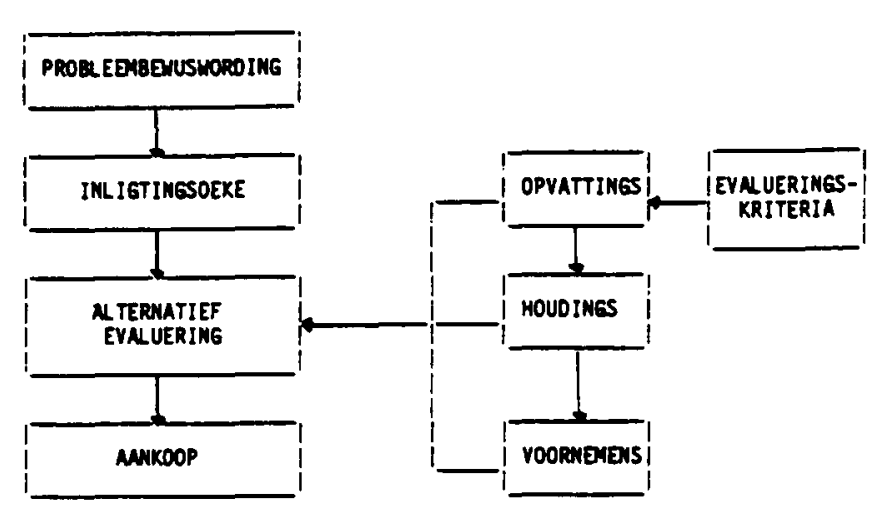

Figuur 1 Die alternatiefevalueringsfase van die verbruiker (Engel, et al., 1986)

motiewe. Die belangrikste eienskappe van evalueringskriteria is die aantal kriteria wat gebruik word in die besluitnemingsproses, asook die relatiewe belangrikheid en opvallendheid ('salience') van elke kriterium. Oor laasgenoemde sê Engel, et al. (1986:96): 'Salience refers to the potential influence each criterion may exert during the comparison process and is often measured in performance.' Die belangrikste corsprong van evalueringskriteria is volgens Cohen (1981:373) waardes, motiewe, inligting en ervaring. Sekere inligting word in 'n persoon se langtermyngeheue geberg en word aan faktore soos vorige ervaring, gesinvoorkeure, persoonlike kommunikasie en reklame ontleen. Verbruikers se omstandighede verskil in vele opsigte van mekaar. Ofskoon dit erken word dat verbruikers almal dieselfde basiese behoeftes het, word verskille aangetref ten opsigte van individuele eienskappe soos motiewe, waardes, lewensstyl en persoonlikheid. Ander verskille is kultuurinvloede, verwysingsgroepe asook gesins- en familiebeïnvloeding. Hierdie veranderlikes kan die besluitnemingsproses van ' $n$ verbruiker by die aankoop van ' $n$ motor beïnvloed en moet as sodanig in ' $n$ bemarker se strategieë ingebou word om vir verskille, indien aanwesig, voorsiening te maak. Assael (1984:311) verklaar dat die swart mark in die V.S.A. genoegsaam van die wit mark verskil dat eersgenoemde as 'n afsonderlike subkultuur beskou kan word.

Verskille tussen rassegroepe wat betref inkooppatrone, pryse, handelsmerke en advertensiemedia oor nie-duursame goedere is deur verskeie navorsers gevind ( Assael, 1984:311-318; Robertson, Zielinski \& Ward, 1984:544-548 en Schiffman \& Kanuk, 1983:433-437). Verskille tussen rassegroepe in verbruikersgedrag ten opsigte van die aankoop van motors is ook vasgestel. Bullock (1961:104) het byvoorbeeld gevind dat daar 'n beduidende verskil tussen Negers en Blankes se siening was wat betref 'n Mercurymotor. Vyftig persent van die Negers het aangedui dat die motor 'n aantreklike ontwerp het terwyl $61 \%$ van die Blankes gesê het dat die ontwerp onaantreklik was. Akers (1968:283-289) se navorsing wat hy gedoen het om 'n vergelyking te tref tussen Neger- en Blanke-eienaarskap van motors, se bevinding was dat Negers wat in dieselfde inkomstekategorie as Blankes is, hoër prysklas motors besit. Verder is bevind dat Negers ook hoër prysmodelle besit - ongeag die fabrikaatnaam. Negers besit ook motors met meer silinders as wat vergelykbare blanke gesinne (met dieselfde inkomste) besit. Berkman \& Gilson (1978:129) sê dat hierdie bevindinge die argument versterk dat Swartes prestige produkte, wat 'n hoë graad van sosiale sigbaarheid het, verkies. Wall (1973:74) is egter van mening dat hoë-middelklas Negers van tradisionele prestige motors soos die Cadillac wegskram en ander luukse motors koop aangesien die Cadillac ' $n$ ' $k$ wasiryk' simbool geword het. In Suid-Afrika het Missen $(1975: 80)$ bevind dat die gewildste motors in Soweto die Volkswagen en Valiant was. Die mees uitstaande koopmotiewe vir die Volkswagen was ekonomiese werkverrigting en vir die Valiant was dit werkverrigting, gerief en grootte. Rousseau (1979:33-46) het 'n kruiskulturele studie van die persepsie oor motors onder studente in Suid-Afrika gedoen. Drie bevolkingsgroepe naamlik Swartes, Blankes en Kleurlinge is in die steekproef opgeneem.

Daar is van projektiewe tegnieke gebruik gemaak waarna inhoudsontleding toegepas is. Van die vernaamste verskille wat gevind was tussen die drie groepe is dat gekleurde en swart respondente die hoogste behoefte vir privaatvervoer, spesifiek na en vanaf werkplek, geprojekteer het. 'n Motoraankoop word ook meer met 'n goeie gebruikte motor geassosieer by hierdie twee groepe as by wit respondente. In die besluitnemingsproses heg die swart respondente 'n hoër waarde aan die opinie van andere terwyl feitelike produkinligting minder prominent was. Wit respondente was meer bewus van prys, ekonomie en kwaliteitsfaktore sowel as veiligheids- en betroubaarheidskenmerke van die motor, as wat die ander twee groepe was. Swart respondente was weer meer van moontlike onderhoudsprobleme bewus as die ander twee groepe. Die ooreenkoms tussen al drie die groepe was dat hulle 'n motor as 'n besitting, waarmee sosiale kontak bewerkstellig kan word, beskou het en dat die besit van 'n motor ook as 'n simbool van status en sukses bestempel word. In die studie van Rousseau (1979) is daar van illustrasies, sinvoltooiing en tekenvoorstellings gebruik gemaak en bevindinge kan alleenlik in daardie konteks vertolk word. Daar is nie vasgestel hoe die respondent in die werklike situasie opgetree het met betrekking tot die keuse van sy eie motor nie.

Rousseau (1981:37-44) het ook navorsing deur middel van projektiewe tegnieke gedoen, onder SuidAfrikaanse swart universiteitstudente, om te bepaal watter sub-bewuste motiewe, onherkende waardes en verbruiksverwagtinge by hulle teenwoordig is by oorweging van die aankoop van 'n motor. Die bevindinge was dat gedrag by die aankoop van 'n motor met sosiale behoeftebevrediging geassosieer kan word asook die statusfaktor wat met motoreienskap gepaard gaan. Verkoopskonsultante word as 'n belangrike bron vir inligtingversameling beskou, gevolg deur gedrukte media soos pamflette, koerante en tydskrifadvertensies. Respondente was baie bewus van prys en onderhoud van die motor tydens die keuses van die verskillende fabrikate. Beperkinge van hierdie navorsing, uit die oogpunt van die onderhawige studie, is die volgende: 
Tabel 1 Demografiese eienskappe van respondente in die steekproef

\begin{tabular}{|c|c|c|c|c|c|c|c|c|c|c|}
\hline \multirow[b]{3}{*}{ Klassifikasie } & \multicolumn{10}{|c|}{ Rassegroep } \\
\hline & \multicolumn{2}{|r|}{ Blankes } & \multicolumn{2}{|r|}{ Kleurlinge } & \multicolumn{2}{|r|}{ Asiērs } & \multicolumn{2}{|r|}{ Swartes } & \multicolumn{2}{|c|}{ Totaal } \\
\hline & $\begin{array}{l}\text { Aan- } \\
\text { tal }\end{array}$ & $\begin{array}{c}\% \text { van Blankes } \\
\text { se totaal }\end{array}$ & $\begin{array}{c}\text { Aan- } \\
\text { tal }\end{array}$ & $\begin{array}{l}\% \text { van Kleur- } \\
\text { linge se totaal }\end{array}$ & $\begin{array}{c}\text { Aan- } \\
\text { tal }\end{array}$ & $\begin{array}{c}\% \text { van Asiërs } \\
\text { se totaal }\end{array}$ & $\begin{array}{c}\text { Aan- } \\
\text { tal }\end{array}$ & $\begin{array}{c}\% \text { van Swartes } \\
\text { se totaal }\end{array}$ & $\begin{array}{c}\text { Aan- } \\
\text { tal }\end{array}$ & $\%$ \\
\hline \multicolumn{11}{|l|}{ 1. Geslag } \\
\hline Manlik & 451 & 78,2 & 95 & 83,3 & 97 & 95,1 & 93 & 85,3 & 736 & 81,6 \\
\hline Vroulik & 126 & 21,8 & 19 & 16,7 & 5 & 4,9 & 16 & 14,7 & 166 & 18,4 \\
\hline \multicolumn{11}{|l|}{ 2. Huistaal } \\
\hline Afrikaans & 251 & 43,5 & 57 & 50,0 & - & - & 4 & 3,7 & 312 & 34,6 \\
\hline Engels & 311 & 53,9 & 57 & 50,0 & 93 & 91,2 & 18 & 16,5 & 479 & 53,1 \\
\hline Ander & 15 & 2,6 & - & - & 9 & 8,8 & 87 & 79,8 & 111 & 12,3 \\
\hline \multicolumn{11}{|l|}{ 3. Onderwyspeil" } \\
\hline St 6 & 2 & 0,3 & 4 & 3,5 & 5 & 4,9 & 5 & 4,6 & 16 & 1,8 \\
\hline St 8 & 34 & 5,9 & 28 & 24,6 & 21 & 20,6 & 31 & 18,4 & 114 & 12,6 \\
\hline Matriek & 203 & 35,2 & 48 & 42,1 & 47 & 46,1 & 48 & 44,0 & 346 & 38,4 \\
\hline Naskoolse diploma & 157 & 27,3 & 22 & 19,3 & 11 & 10,8 & 15 & 13,8 & 205 & 22,7 \\
\hline Universiteitsgraad & 181 & 31,3 & 12 & 10,5 & 18 & 17,6 & 10 & 9,2 & 221 & 24,5 \\
\hline \multicolumn{11}{|l|}{ 4. Beroepsgroep } \\
\hline Polisie/weermag & 12 & 2,1 & 7 & 6,1 & 9 & 8,8 & 1 & 0,9 & 29 & 3,2 \\
\hline Klerklik/verkope & 122 & 21,1 & 29 & 25,4 & 41 & 40,2 & 30 & 27,6 & 222 & 24,6 \\
\hline Professioneel & 153 & 26,5 & 32 & 28,1 & 18 & 17,6 & 25 & 22,9 & 228 & 25,3 \\
\hline Vakman/geskoolde werker & 44 & 7,6 & 16 & 14,0 & 10 & 9,8 & 7 & 6,4 & 77 & 8,5 \\
\hline Eie besigheid & 40 & 6,9 & 9 & 7,9 & 10 & 9,8 & 26 & 23,9 & 85 & 9,4 \\
\hline Huisvrou/tuisteskepper & 8 & 1,4 & 2 & 1,8 & - & - & 2 & 1,8 & 12 & 1,3 \\
\hline Ongeskoolde werker & - & - & 1 & 0,9 & - & - & 3 & 2,8 & 4 & 0,4 \\
\hline Student & 5 & 0,9 & 5 & 4,4 & 1 & 1,0 & 2 & 1,8 & 13 & 1,4 \\
\hline Bestuur/uitvoerend & 161 & 27,9 & 7 & 6,1 & 10 & 9,8 & 6 & 5,5 & 184 & 20,4 \\
\hline Fabriekswerker & 7 & 1,2 & 3 & 2,6 & 2 & 2,0 & 3 & 2,8 & 15 & 1,7 \\
\hline Afgetree & 12 & 2,1 & 2 & 1,8 & 1 & 1,0 & 2 & 1,8 & 17 & 1,9 \\
\hline WerkJoos & 1 & 0,2 & 1 & 0,9 & - & - & - & - & 2 & 0,2 \\
\hline Ander (bv. vlieënier, & & & & & & & & & & \\
\hline diplomaat, lugwaardin) & 12 & 2,1 & - & - & - & - & 2 & 1,8 & 14 & 1,6 \\
\hline \multicolumn{11}{|l|}{ 5. Ouderdom } \\
\hline $18-24$ & 42 & 7,3 & 16 & 14,0 & 15 & 14,7 & 1 & 0,9 & 74 & 8,2 \\
\hline $25-30$ & 97 & 16,8 & 32 & 28,1 & 27 & 26,5 & 15 & 13,8 & 171 & 19,0 \\
\hline $31-35$ & 111 & 19,2 & 21 & 18,4 & 21 & 20,6 & 24 & 22,0 & 177 & 19,6 \\
\hline $36-45$ & 177 & 30,7 & 26 & 22,8 & 28 & 27,5 & 41 & 37,6 & 272 & 30,2 \\
\hline $46-55$ & 109 & 18,9 & 17 & 14,9 & 8 & 7,8 & 25 & 22,9 & 159 & 17,6 \\
\hline $56-64$ & 32 & 5,5 & 2 & 1,8 & 3 & 2,9 & 3 & 2,8 & 40 & 4,4 \\
\hline $65+$ & 9 & 1,6 & - & - & - & - & - & - & 9 & 1,0 \\
\hline \multicolumn{11}{|l|}{ 6. Huwelikstatus } \\
\hline Huidig getroud & 435 & 75,4 & 74 & 64,9 & 72 & 70,6 & 79 & 72,5 & 660 & 73,2 \\
\hline Geskei & 52 & 9,0 & 4 & 3,5 & 1 & 1,0 & 4 & 3,6 & 61 & 6,7 \\
\hline Nooit getroud & 79 & 13,7 & 34 & 29,8 & 28 & 27,4 & 23 & 21,1 & 164 & 18,2 \\
\hline Wedustaat & 11 & 1,9 & 2 & 1,8 & 1 & 1,0 & 3 & 2,8 & 17 & 1,9 \\
\hline \multicolumn{11}{|c|}{$\begin{array}{l}\text { Wedustaat } \\
\text { 7. Bruto huishoudelike maandelikse inkomste }\end{array}$} \\
\hline$<\mathrm{R} 600$ & 6 & 1,0 & 6 & 5,3 & 6 & 5,9 & 9 & 8,3 & 27 & 3,0 \\
\hline R600-R999 & 21 & 3,6 & 19 & 16,7 & 25 & 24,5 & 24 & 22,0 & 89 & 9,9 \\
\hline R1000-R1499 & 43 & 7,5 & 25 & 21,8 & 23 & 22,5 & 27 & 24,8 & 118 & 13,1 \\
\hline R1500-R1999 & 75 & 13,0 & 22 & 19,3 & 22 & 21,6 & 16 & 14,7 & 135 & 15,0 \\
\hline R2000-R2999 & 174 & 30,2 & 22 & 19,3 & 13 & 12,7 & 14 & 12,8 & 223 & 24,7 \\
\hline R3000-R3999 & 147 & 25,5 & 10 & 8,8 & 4 & 3,9 & 11 & 10,1 & 172 & 19,1 \\
\hline \multirow[t]{2}{*}{ R4000+ } & 111 & 19,2 & 10 & 8,8 & 9 & 8,8 & 8 & 7,3 & 138 & 15,3 \\
\hline & \multicolumn{2}{|r|}{$n=577$} & \multicolumn{2}{|r|}{$n=114$} & & $=102$ & $n=1$ & 109 & $n=902$ & \\
\hline
\end{tabular}

\footnotetext{
- Hoogste vlak
} 
daar is nie onderskei tussen nuwe of gebruikte motors nie; die respondente was jong swartes met 'n relatief hoë onderwyspeil; die koopmotiewe was nie na 'n bepaalde fabrikaat motor herlei nie; die geografiese omvang was slegs tot een metropool beperk; en geen vergelyking is met ander rassegroepe gedoen nie.

'n Vergelykende studie in Suid-Afrika oor die verskillende rassegroepe ten opsigte van evalueringskriteria by die aankoop van 'n motorvoertuig is nog nie in gepubliseerde navorsing teëgekom nie.

\section{Motode}

Die steekproef het bestaan uit 902 verbruikers van hoofsaaklik metropolitaanse gebiede in Suid-Afrika, wat tussen Desember 1985 en Mei 1986 'n nuwe of gebruikte motor vir privaatgebruik gekoop het. Binne hierdie geografiese gebiede is motorhandelaars vooraf geïdentifiseer om 'n verteenwoordigende verdeling van die onderskeie motorvervaardigers in die steekproef op te neem. Vir ' $n$ volledige bespreking van die steekproefmetode en meetinstrument word verwys na Du Plessis (1986: 164-190).

Die demografiese eienskappe van respondente in die steekproef verskyn in Tabel 1.

Vir doeleindes van hierdie studie word produkattribute in die konteks van die belangrikheid daarvan vir die verbruiker gebruik, soos deur hom waargeneem, en nie vanuit 'n objektiewe vlak van belangrikheid, intrinsiek in die produk nie (Bloch \& Richins, 1983:69).

Vyf en sestig kriteria wat deur 'n koper oorweeg word by die aankoop van ' $n$ motor, word in hierdie studie gebruik om te bepaal watter relatiewe belangrikheid aan evalueringskriteria geheg word. Hierdie kriteria verskyn in Tabel 2.

Die metode van data-insameling wat gevolg is het bestaan uit ' $n$ gestruktureerde vraelys wat kopers by die motorhandelaar moes voltooi nadat 'n motor gekoop is. Evalueringskriteria (in Tabel 2) het die belangrikste komponent van die vraelys verteenwoordig. Responsies op elke kriterium word op 'n sespuntskaal van een tot ses aangeslaan. Die skaalwaarde van een dui aan dat die kriterium vir die respondent totaal onbelangrik was by die keuse van die betrokke motor, terwyl die sesde waarde uiters belangrikheid vir die verbruiker aantoon. Die skaalwaardes kan gedefinieer word as diskrete posisies op ' $n$ veronderstelde kontinuum van belangrikheid vir die respondent (Boote, 1981:54). Argumente oor die optimum aantal responsie-alternatiewe vir 'n skaal bestaan sedert die eerste gebruik van sodanige meetinstrument (Cox, 1980:407). Na 'n omvattende literatuurstudie het Cox (1980:420) tot die gevolgtrekking gekom dat skale met twee of drie responsie-alternatiewe, in die algemeen, onvoldoende is aangesien dit nie genoegsame inligting oordra nie en dat dit respondente frustreer en onderdruk. Verder is bevind dat die marginale voordeel om meer as nege responsie-alternatiewe te gebruik, minimaal is. Die optimum aantal responsie-alternatiewe lê tussen vyf en nege. In die onderhawige geval waar 'n responsie geposisioneer word op 'n kontinuum van enkelattribute is vyf responsiealternatiewe voldoende (Cox, 1980:420). 'n Onewe getal responsie-alternatiewe is verkieslik waar die respondent regmatig ' $n$ neutrale posisie kan inneem. Die kriteria in hierdie vraelys leen hulself nie tot ' $n$ onsydige keuse nie en ses responsie-alternatiewe is derhalwe beskou as 'n aanvaarbare aantal om die kriteria te meet. Die ewegetal sal ook bydra om die moontlikheid van 'n sentrale geneigdheidsfout uit te skakel (Huysamen, 1983:111). Alhoewel die aantal responsie-alternatiewe nie absoluut krities in hierdie studie is nie, is die gebruik van ses responsie-alternatiewe verdedigbaar. Nunnally (1967:522) meld ook dat daar in die meeste gevalle ' $n$ geringe voordeel is om 'n ewegetal responsiealternatiewe te gebruik en illustreer dit met behulp van 'n sesstapskaalvoorbeeld. Wat geldigheid betref verklaar Nunnally (1967:521) dat daar 'n afplatting by sewe stappe begin intree en na 11 stappe is daar min verhoging in geldigheid te verkry. Die nulhipotese is met behulp van eenrigting variansie-ontleding getoets ( $F$-toets).

Tabol 2 Evalueringskriteria by die aankoop van 'n motorvoertuig vir privaatgebruik

\begin{tabular}{|c|c|}
\hline 1. Gehalte van vakmanskap & 34. Padtoetsverslae \\
\hline 2. Onbeperkte uitsig & 35. Kredietreëlings \\
\hline 3. Reputasie van motorvervaardigers & 36. Lugtoevoerstelsel \\
\hline 4. Verhouding met verkooppersoneel & 37. Aankoopprys \\
\hline van handelaar & 38. Stilering/voorkoms \\
\hline 5. Bagasieruimte & 39. Versnelling \\
\hline 6. Statusindruk van motor & 40. Veiligheidskenmerke \\
\hline 7. Stilheid van enjin/transmissie & 41. Uitgebreide handelaarnetwerk \\
\hline 8. Instandhoudingskoste & 42. Toetsrit \\
\hline 9. Fatsoen/vorm & 43. Gerief vir passasiers \\
\hline 10. Gemak van voorsitplekke & 44. Hoëspoedverrigting \\
\hline 11. Enjingrootte & 45. Spesiale aanbieding \\
\hline 12. Geraasvlak binne motor & 46. Mening van vriende \\
\hline 13. Betroubaarheid van model & 47. Invloed van verkooppersoneel \\
\hline 14. Luuksheid binne & 48. Radio-advertensie \\
\hline 15. Lae loopkoste & 49. Rygemak \\
\hline 16. Prestigewaarde & 50. Reikafstand van brandstoftenk \\
\hline 17. Mening van kollegas & 51. Padhouvermoë \\
\hline 18. Toekomstige herverkoopwaarde & 52. Reputasie van handelaar \\
\hline 19. Houding van verkoopperssoneel & 53. TV-advertensie \\
\hline 20. Binneruimte & 54. Ruimheid vir bestuurder \\
\hline 21. Werkverrigting van enjin & 55. Agterwielaandrywing \\
\hline 22. Land van herkoms & 56. Ruimheid vir agterpassasiers \\
\hline 23. Reputasie van model & 57. Gemak van bestuur \\
\hline 24. Voorkoms van vertoonkamer & 58. Spieëltjie op bestuurder se \\
\hline 25. Beskikbaarheid van onderdele & sonskerm \\
\hline 26. Gemak van agtersitplekke & 59. Beenruimte voor \\
\hline 27. Kontantafslag & 60. Ligging van handelaar \\
\hline 28. Instrumentasic van paneelbord & 61. Koste van onderdele \\
\hline 29. Brandstofdoeltreffendheid & 62. Mening van familie \\
\hline 30. Enjinkrag & 63. Tegniese gevorderdheid \\
\hline 31. Waarborgtydperk & 64. Voorwielaandrywing \\
\hline 32. Vorige ervaring met handelaar & 65. Goeie inruilwaarde vir vorige \\
\hline $\begin{array}{l}\text { 33. Reputasie van na-verkope diens } \\
\text { ondersteuning }\end{array}$ & motor \\
\hline
\end{tabular}


Meer as twee groepe (verbruikers) is egter hierby betrokke en om verskille in die evaluering van kriteria tussen hulle te bepaal word die toepaslike prosedure van Scheffé se post-hoc-vergelykingstoets gebruik om statisties beduidende vergelykings op te spoor (in Downie \& Heath, 1970:221).

\section{Resultate}

Die variansie-ontleding met evalueringskriteria het getoon dat daar beduidende verskille op die 0,01-vlak ten opsigte van 49 uit die 65 evalueringskriteria, met betrekking tot die verskillende rassegroepe is, terwyl daar verder beduidende verskille op die 0,05 -vlak ten opsigte van drie evalueringskriteria is. Onbeduidende verskille kom by 13 evalueringskriteria $(20 \%)$ voor, te wete: gehalte van vakmanskap ( $\mathrm{nr}$ 1), reputasie van motorvervaardiger ( $\mathrm{nr} 3$ ), betroubaarheid van die model (nr 13), houding van verkooppersoneel ( $\mathrm{nr}$ 19), reputasie van model (nr 23), kontantafslag ( $\mathrm{nr} 27$ ), reputasie van na-verkope diensondersteuning ( $\mathrm{nr} 33$ ), lugtoevoerstelsel ( $\mathrm{nr}$ 36), aankoopprys ( $\mathrm{nr} 37$ ), uitgebreide handelaarnetwerk ( $\mathrm{nr} 41$ ), mening van vriende ( $\mathrm{nr} 46)$, reputasie van handelaar ( $\mathrm{nr} 52$ ) en goeie inruilwaarde vir vorige motor ( $\mathrm{nr} 65$ ). Die grootste verskille tussen rassegroepe, met betrekking tot hulle evaluering van die relatiewe belangrikheid van die kriteria kom by kredietreëlings $(F$-waarde $=101,71)$, agterwielaandrywing $(F$-waarde $=78,16)$, enjinkrag $(F$ waarde $=70,27)$, spieëltjie op bestuurder se sonskerm $(F$-waarde $=56,08)$ en padtoetsverslae $(F$-waarde $=$ 52,75 ) voor. Die nulhipotese word dus ten opsigte van 52 evalueringskriteria verwerp ten gunste van die alternatiewe hipotese.

Waar presies hierdie verskille is, is met behulp van Scheffé se post hoc-vergelykingstoets opgespoor (Downie \& Heath, 1970:221). Vergelykings wat met Scheffé se toets as beduidend gevind is, word in Tabel 3 aangetoon.

Volgens Tabel 3 kan afgelei word dat die grootste verskille tussen Blankes en Swartes (by $66 \%$ van die evalueringskriteria) en tussen Blankes en Asiërs (by $43 \%$ van die evalueringskriteria) voorkom. Die kleinste getal verskille tussen rassegroepe, kom tussen Kleurlinge en Blankes (25\%), Kleurlinge en Swartes $(25 \%)$ en tussen Asiërs en Swartes (22\%) voor. Daar is bykans geen verskil tussen Kleurlinge en Asiërs nie $(0,03 \%)$. Die tien belangrikste verskille in evalueringskriteria tussen Blankes en Swartes het voorgekom by: enjinkrag ( $\mathrm{nr} 30)$, agterwielaandrywing ( $\mathrm{nr} 55$ ), padtoetsverslae (nr 43), spieëltjie op bestuurder se sonskerm (nr 58), stilheid van enjin/transmissie (nr 7), waarborgtydperk (nr 1), prestige waarde (nr 16), toetsrit ( $\mathrm{nr}$ 42), koste van onderdele ( $\mathrm{nr}$ 61) en werkverrigting (nr 21).

Van die belangrikste verskille tussen Blankes en Asiërs met betrekking tot die evaluering van die relatiewe belangrikheid van kriteria het by die volgende evalueringskriteria na vore gekom: kredietreëlings (nr 35), agterwielaandrywing ( $\mathrm{nr} 55$ ), spieëltjie op bestuurder se sonskerm (nr 58), gerief vir passasiers ( $\mathrm{nr}$
43), enjinkrag ( $\mathrm{nr} 39$ ), gemak van agtersitplekke ( $\mathrm{nr} 26$ ), spesiale aanbieding ( $\mathrm{nr} 45$ ) en toetsrit (nr 42). Tussen Blankes en Kleurlinge is die belangrikste verskille in evalueringskriteria soos volg: gemak van voorsitplekke (nr 10), agterwielaandrywing ( $\mathrm{nr} 55$ ), padtoetsverslae ( $n r$ 34), stilheid van enjin/transmissie (nr 7) en spesiale aanbieding (nr 45). Enjinkrag (nr 30), bagasieruimte (nr $5)$, waarborgtydperk ( $\mathrm{nr} 31$ ), ligging van handelaar (nr 60 ) en vorige ervaring met handelaar ( $\mathrm{nr} 32)$ is van die belangrikste verskille wat tussen Kleurlinge en Swartes voorgekom het. Die belangrikste verskille in evalueringskriteria tussen Asiërs en Swartes het by die volgende kriteria voorgekom: kredietreëlings (nr 35), enjinkrag ( $\mathrm{nr}$ 30), waarborgtydperk (nr 31) en padhouvermoë (nr 51). Slegs twee beduidende verskille op die 0,01-vlak het tussen Asiërs en Kleurlinge met betrekking tot evalueringskriteria voorgekom, naamlik: kredietreëlings (nr 35) en gemak van voorsitplekke ( $\mathrm{nr} 10)$.

\section{Bespreking en Govolgtrekkings}

Die doelstellings van hierdie studie was om te bepaal wat die relatiewe belangrikheid van verskillende evalueringskriteria vir verbruikers by die aankoop van 'n motor is. Ook wou die outeur bepaal of daar verskille en/of ooreenkomste bestaan tussen verskillende rassegroepe wat betref die relatiewe belangrikheid van evalueringskriteria by die aankoop van ' $n$ motor.

Daar is bevind dat beduidende verskille op die 0,01vlak ten opsigte van 49 uit die 65 evalueringskriteria, met betrekking tot die verskillende rassegroepe bestaan. Geen plaaslike literatuur, waar die relatiewe belangrikheid van evalueringskriteria ten opsigte van die onderskeie rassegroepe nagevors is, kon opgespoor word nie en die resultate van hierdie studie is moontlik die eerste.

Twee van die evalueringskriteria wat 'n beduidende verskil op die 0,01-vlak toon wat Blankes en Swartes betref, is prestigewaarde en statusindruk van 'n motor. Daar is bevind dat die gemiddelde evaluering deur Blankes van hierdie kriterium 3,35 en vir Swartes 4,08 was waar 6 die maksimumwaarde was wat behaal kon word. Hierdie bevinding rym met Rousseau (1979) se afleiding dat 'n motor 'n statussimbool en sukses kan verteenwoordig waarop Swartes trots is. 'n Indirekte afleiding deur Berkman \& Gilson (1978) oor die navorsing van Akers (1968) was dat Swartes prestige produkte, wat 'n hoë graad van sosiale sigbaarheid het, verkies. Die bevinding in die onderhawige studie kan moontlik hierdie afleiding onderskraag. Bullock (1961) het bevind dat daar beduidende verskille tussen Blankes en Negers se siening oor 'n motor se ontwerp was. Indien hierdie ontwerppersepsie gelyk gestel word aan die evalueringskriterium fatsoen/vorm in die huidige studie, word dieselfde resultaat verkry. 'n Beduidende verskil $(0,01)$ kom tussen Blankes en Swartes voor wat die relatiewe belangrikheid van hierdie kriterium betref. In die geval van fatsoen/vorm ken Blankes 'n gemiddeld van 3,97 daaraan toe, terwyl Swartes 'n gemiddeld van 4,35 daaraan toeken. Beduidende verskille op die 0,01vlak het ook tussen Blankes en Swartes voorgekom, ten 
Tabel 3 Scheffé se toets met betrekking tot die rassegroepe se evaluering van kriteria vir alle grootte motorkategorieë

\begin{tabular}{|c|c|c|c|c|c|c|c|}
\hline \multirow[b]{2}{*}{$\begin{array}{l}\text { Kriterium } \\
\text { nommer }\end{array}$} & \multirow[b]{2}{*}{ Beskrywing } & \multicolumn{6}{|c|}{ Vergelyking } \\
\hline & & $\begin{array}{c}\text { Blankes } \\
\text { vs } \\
\text { Kleurlinge } \\
\text { (F-waarde) }\end{array}$ & $\begin{array}{c}\text { Blankes } \\
\text { vs } \\
\text { Asiërs } \\
\text { (F-waarde) }\end{array}$ & $\begin{array}{c}\text { Blankes } \\
\text { vs } \\
\text { Swartes } \\
\text { (F-waarde) }\end{array}$ & $\begin{array}{l}\text { Kleurlinge } \\
\text { vs } \\
\text { Asiërs } \\
\text { ( } F \text {-waarde) }\end{array}$ & $\begin{array}{c}\text { Kleurlinge } \\
\text { vs } \\
\text { Swartes } \\
\text { ( } F \text {-waarde) }\end{array}$ & $\begin{array}{c}\text { Asiërs } \\
\text { vs } \\
\text { Swartes } \\
\text { (F-waarde) }\end{array}$ \\
\hline 2. & Onbeperkte uitsig & 1,56 & 3,20 & $20,21^{\text {a }}$ & 0,22 & 6,50 & 4,04 \\
\hline 4. & $\begin{array}{l}\text { Verhouding met verkooppersoneel van } \\
\text { handelaar }\end{array}$ & 0,08 & 1,86 & $10,32^{\mathrm{b}}$ & 1,65 & 7,39 & 1,88 \\
\hline 5. & Bagasieruimte & 3,35 & 0,02 & $27,41^{\star \prime}$ & 1,57 & $30,04^{a}$ & $16,73^{a}$ \\
\hline 6. & Statusindruk van motor & 2,31 & $10,14^{\mathrm{b}}$ & $24,71^{\star}$ & 1,87 & 7,36 & 1,65 \\
\hline 7. & Stilheid van enjin/transmissie & $21,18^{a}$ & $18,83^{\mathrm{a}}$ & $75,70^{\circ}$ & $\mathbf{0}$ & $10,64^{b}$ & $10,32^{b}$ \\
\hline 8. & Instandhoudingskoste & 7,81 & $10,44^{b}$ & $28,96^{\mathrm{a}}$ & 0,20 & 4,23 & 2,43 \\
\hline 9. & Fatsoen/vorm & 0,09 & 0,10 & $9,50^{b}$ & 0,21 & 6,91 & 4,39 \\
\hline 10. & Gemak van voorsitplekke & $79,93^{2}$ & 0,15 & $13,36^{\star}$ & $49,34^{a}$ & $15,93^{a}$ & $9,42^{b}$ \\
\hline 11. & Enjingrootte & 0,86 & 0 & $13,20^{\circ}$ & 0,54 & 4,51 & 7,81 \\
\hline 12. & Geraasvlak binne motor & 1,13 & 4,82 & 3,13 & 0,86 & 0,32 & 0,14 \\
\hline 14. & Luuksheid binne & 0,05 & $10,62^{b}$ & $18,06^{a}$ & 7,46 & $12,10^{a}$ & 0,46 \\
\hline 15. & Lae loopkoste & 3,51 & $10,39^{b}$ & 2,36 & 1,28 & 0,06 & 1,82 \\
\hline 16. & Prestige waarde & 6,73 & $9,04^{b}$ & $54,36^{a}$ & 0,18 & $14,16^{\mathrm{a}}$ & $10,54^{b}$ \\
\hline 17. & Mening van kollegas & 1,66 & $8,67^{b}$ & $10,27^{b}$ & 1,82 & 2,29 & 0,02 \\
\hline 18. & Toekomstige herverkoopwaarde & 0,44 & 0,32 & $14,15^{a}$ & 0 & 5,88 & 5,82 \\
\hline 20. & Binneruimte & 0,76 & 1,86 & $19,33^{n}$ & 0,17 & 7,61 & 5,16 \\
\hline 21. & Werkverrigting van enjin & $15,99^{\circ}$ & $18,19^{\circ}$ & $43,68^{a}$ & 0,13 & 4,38 & 2,84 \\
\hline 22. & Land van herkoms & $13,33^{\circ}$ & $9,14^{b}$ & $23,59^{n}$ & 0,13 & 0,99 & 1,76 \\
\hline 24. & Voorkoms van vertoonkamer & 2,57 & 2,76 & 2,03 & 0,01 & 0,01 & 0,05 \\
\hline 25. & Beskikbaarheid van onderdele & 4,08 & $9,51^{b}$ & $15,64^{*}$ & 0,83 & 2,37 & 0,35 \\
\hline 26. & Gemak van agtersitplekke & $14,44^{n}$ & $23,14^{a}$ & $21,35^{2}$ & 0,87 & 0,48 & 0,06 \\
\hline 27. & Instrumentasie van paneelbord & 1,43 & 1,76 & $10,54^{b}$ & 0,02 & 2,61 & 2,03 \\
\hline 29. & Brandstofdoeltreffendheid & 5,14 & $12,97^{\circ}$ & $34,67^{\circledR}$ & 1,29 & $8,16^{b}$ & 2,74 \\
\hline 30. & Enjinkrag & $9,95^{b}$ & $24,52^{\star}$ & $134,47^{\mathrm{a}}$ & 2,34 & 43,92 & $24,31^{\mathrm{a}}$ \\
\hline 31. & Waarborgtydperk & $8,22^{b}$ & 4,49 & $70,41^{*}$ & 0,23 & $18,91^{*}$ & $22,19^{a}$ \\
\hline 32. & Vorige ervaring met handelaar & 0,02 & 1,67 & 27,97 & 0,82 & $16,09^{*}$ & $9,02^{b}$ \\
\hline 34. & Padtoetsverslae & $22,96^{\circ}$ & $14,86^{n}$ & $89,30^{\circ}$ & 0,32 & $13,70^{*}$ & $17,30^{2}$ \\
\hline 35. & Kredietreëlings & $11,69^{n}$ & $197,20^{n}$ & $31,23^{=}$ & $72,18^{\mathrm{a}}$ & 3,03 & $45,05^{\mathrm{a}}$ \\
\hline 38. & Stilering/voorkoms & 1,02 & 6,98 & 0,83 & $\mathbf{8 , 0 7 ^ { \mathbf { b } }}$ & 2,20 & 1,88 \\
\hline 39. & Versnelling & 6,29 & $12,86^{\mathrm{a}}$ & $15,47^{\mathrm{a}}$ & 0,88 & 1,32 & 0,04 \\
\hline 40. & Veiligheidskenmerke & 4,67 & $11,63^{a}$ & $15,40^{\circ}$ & 1,13 & 1,97 & 0,10 \\
\hline 42. & Toetsrit & 19,19 & $21,91^{*}$ & $50,06^{*}$ & 0,16 & 4,69 & 2,94 \\
\hline 43. & Gerief vir passasiers & 5,45 & $26,33^{2}$ & 1,21 & 5,24 & 0,86 & $10,02^{b}$ \\
\hline 44. & Hoëspoedverrigting & $9,07^{b}$ & $18,06^{\mathrm{a}}$ & 5,89 & 1,18 & 0,17 & 2,17 \\
\hline 45. & Spesiale aanbieding & $19,71^{\bullet}$ & $22,37^{a}$ & $17,80^{\infty}$ & 0,15 & 0,01 & 0,24 \\
\hline 47. & Invloed van verkooppersoneel & 0,17 & 2,50 & $7,98^{\mathrm{b}}$ & 2,43 & 6,35 & 0,82 \\
\hline 48. & Radio-advertensie & $8,75^{b}$ & 7,12 & $26,70^{n}$ & 0,02 & 3,12 & 3,37 \\
\hline 49. & Rygemak & 0,85 & 7,34 & $9,78^{b}$ & 2,09 & 3,01 & 0,07 \\
\hline 50. & Reikafstand van brandstoftenk & $13,42^{\bullet}$ & $15,89^{\circ}$ & $32,38^{2}$ & 0,15 & 2,67 & 1,45 \\
\hline 51. & Padhouvermoë & 4,03 & $13,50^{2}$ & 4,91 & 1,92 & $10,65^{b}$ & $20,65^{*}$ \\
\hline 53. & TV-advertensie & 2,22 & 2,00 & 5,87 & $\mathbf{0}$ & 0,56 & 0,54 \\
\hline 54. & Ruimheid vir bestuurder & 1,58 & 0,13 & 6,46 & 1,51 & 1,04 & 4,88 \\
\hline 55. & Agterwielaandrywing & $27,21^{*}$ & $59,26^{n}$ & $98,91^{a}$ & 4,60 & $14,16^{\circ}$ & 2,36 \\
\hline 56. & Ruimheid vir agterpassasiers & 5,88 & $15,42^{\mathrm{z}}$ & $27,34^{\star}$ & 1,62 & 4,93 & 0,81 \\
\hline 57. & Gemak van bestuur & 2,93 & 0,03 & $26,34^{n}$ & 2,06 & 7,24 & $16,28^{a}$ \\
\hline 58. & Spieëltjie op bestuurder se sonskerm & $16,81^{\bullet}$ & $36,26^{a}$ & $80,31^{\mathbf{a}}$ & 2,76 & $14,82^{2}$ & 4,40 \\
\hline 59. & Beenruimte voor & 1,74 & 2,87 & $16,97^{\mathrm{a}}$ & 0,12 & 4,85 & 3,25 \\
\hline 60. & Ligging van handelaar & 0,38 & 1,88 & $34,18^{\mathrm{a}}$ & 0,38 & $16,71^{\star}$ & $11,32^{b}$ \\
\hline 61. & Koste van onderdele & 6,25 & $16,38^{\bullet}$ & 49,09 & 1,71 & $12,59^{a}$ & 4,65 \\
\hline 62. & Mening van familie & 8,93 & $11,44^{*}$ & $37,32^{2}$ & 0,18 & 6,13 & 3,98 \\
\hline 63. & Tegniese gevorderdheid & 0,59 & 2,46 & $10,46^{b}$ & 0,43 & 3,74 & 1,51 \\
\hline 64. & Voorwielaandrywing & 1,71 & 3,57 & $32,68^{2}$ & 0,26 & $11,94^{\circ}$ & $8,18^{b}$ \\
\hline
\end{tabular}

- Beduidend op die 0,01-vlak; ' Beduidend op die 0,05-vlak 
opsigte van die volgende evalueringskriteria: instandhoudingskoste; beskikbaarheid van onderdele; en koste van onderdele (sien Tabel 3). Die gemiddelde waarde wat Blankes aan hierdie evalueringskriteria toegeken het, was in alle gevalle laer as die gemiddelde waarde wat deur Swartes toegeken is. Hierdie resultaat is in ooreenstemming met Rousseau (1979) se bevinding dat Swart respondente meer van moontlike onderhoudsprobleme bewus is as wat Blankes en Kleurlinge is. In die geval van Kleurlinge en Swartes was daar ' $n$ beduidende verskil op die 0,01-vlak ten opsigte van koste van onderdele en hier was die gemiddelde waarde wat deur Kleurlinge daaraan toegeken was 4,75 en Swartes se gemiddelde waarde 5,29 wat rym met Rousseau (1979) se bevindinge. Enjinkrag en werkverrigting is ander beduidende verskille wat tussen Blankes en Swartes voorgekom het. Daar kan bespiegel word dat Swartes tradisioneel aan groot motors geheg/ gewoond was en dat hulle 'n hoë waarde op hierdie kriteria plaas. Agterwielaandrywing word ook deur Swartes hoër aangeslaan en 'n afleiding wat hieruit gemaak kan word is dat hulle meer skepties is ten opsigte van voorwielaandrywing. Laasgenoemde bevat 'n risikoen onsekerheidsfaktor wat instandhoudingsaspekte betref. Hierdie spekulasie word versterk in hulle evaluering van die reeds genoemde instandhoudingskriteria waar die gemiddelde evaluerings daarvan deurgaans hoër as die van Blankes was.

Die verskil in evaluering van die kriterium waarborgtydperk, is ietwat verrassend aangesien daar verwag sou word dat dit vir beide Blankes en Swartes ewe belangrik sou wees.

Asiërs se hoër gemiddelde evaluering van kriteria soos kredietreëlings, toetsrit en spesiale aanbieding teenoor die van Blankes kan moontlik daarop dui dat hierdie aspekte meer in die verkoopsonderhandelingsituasie beklemtoon moet word.

\section{Slotopmerkings}

Die bevindinge in hierdie studie hou belangrike implikasies vir verskeie belangegroepe in: Motorvervaardigers kan hulle produkontwerpe aanpas om veranderde verbruikersbehoeftes te bevredig - gesien in die lig van moontlike verskuiwings in marksegmente; motorhandelaars kan hulle strategieë in die verkoopsonderhandelingsituasie verander om toepaslike evalueringskriteria wat vir sekere kopers meer belangrik is, diskreet te aksentueer; reklamepraktisyns kan advertensieboodskappe aan teikenmarksegmente differensieer en laastens kan die bevindinge deur akademici gebruik word as vertrekpunt vir verdere eksplorasie. Die benadering wat gevolg is om te bepaal of, en waar, verskille tussen die rassegroepe bestaan met betrekking tot die relatiewe belangrikheid van evalueringskriteria kan moontlik bevraagteken word. Alle grootte motors is globaal in die ontleding gebruik en geen onderskeid is tussen klein, medium en groot kategorie motors of verskillende motormodelle getref nie. Die doelwit was egter om slegs te bepaal of daar verskille is en waar die verskille met betrekking tot die verskillende rassegroepe is. Om die grootte en modelle van motors se invloed te bepaal, is die terrein van 'n opvolgstudie.

\section{Erkenning}

Dank word betuig aan die Raad vir Geesteswetenskaplike Navorsing vir finansiële bystand in die vorm van 'n beurstoekenning vir doktorale studie.

\section{Summary}

In the South African motor vehicle market the buyers display a heterogenous composition of race, culture, gender, age, income, values, attitudes, and motives. The white segment of the market has nearly reached a saturation level whereas the coloured, Asian and black segments show signs of positive growth. Relatively few research studies have been conducted and published in South Africa with regard to the differences and/or similarities between the various race groups' decisionmaking process - especially when buying a car. It is therefore important to obtain reliable information on consumers' behaviour when purchasing a motor vehicle.

A study was conducted to determine the relative importance of various evaluation criteria for consumers buying a car. The sample consisted of 902 consumers of all race groups, mainly in metropolitan areas in South Africa, who bought a new or used car for private use during the period December 1985 - May 1986. The composition of the sample was 577 whites, 114 coloureds, 102 Asians and 109 blacks.

Sixty-five evaluation criteria were used in a selfadministered, structured questionnaire. Consumers had to complete the questionnaire in the dealer's showroom after the deal was closed. Their perceptions of the relative importance of each criterion were determined on a six-point scale which ranged from 1 (totally unimportant) to 6 (extremely important).

By means of analysis of variance it was found that there were 52 significant differences between the race groups with respect to the various evaluation criteria.

Scheffé's post hoc comparison test showed that there were significant differences between (a) blacks and whites (66\% of the evaluation criteria); (b) whites and Asians (43\%); (c) whites and coloureds (25\%); (d) coloureds and blacks (25\%); and (e) Asians and blacks $(22 \%)$. Only two significant differences occurred between Asians and coloureds with regard to the relative importance of evaluation criterion.

The results of the study have important implications for motor manufacturers, dealers and advertising agencies. Observed differences could be incorporated in revised marketing strategies to offer consumers needrelated products and differentiated communication messages.

\section{Vermysings}

Akers, F.C. 1968. Negro and white automobile behavior: new evidence. J. Market. Res., vol. 5 (August).

Assael, H. 1984. Consumer behavior and marketing action. 2nd Edition. Boston: Kent Publishing Co. 
Berkman, H.W. \& Gilson, C.C. 1978. Consumer behavior. California: Dickenson Publishing Co. Inc.

Bloch, P.H. \& Richins, M.L. 1983. A theoretical model for the study of product importance perceptions. J. Market., vol. 47 (Summer).

Boote, A.S. 1981. Reliability testing of psychographic scales. J. Advert. Res., vol. 21, no.5 (October).

Bullock, H.A. 1961. Consumer motivations in Black and White - I. Harv. Bus. Rev., vol. 39 (May/June).

Cohen, D. 1981. Consumer behavior. New York: Random House Inc.

Cox, E.P. 1980. The optimal number of response alternatives for a scale: a review. J. Market. Res., vol. XVII (November).

Downie, N.M. \& Heath, R.W. 1970. Basic statistical methods. New York: Harper \& Row Publishers.

Du Plessis, P.J. 1986. Verbruikersgedrag by die aankoop van 'n motorvoertuig. Ongepubliseerde DBL-proefskrif. Pretoria: Universiteit van Suid-Afrika.

Engel, J.F., Blackwell, R.D. \& Miniard, P.W. 1986. Consumer behavior. 5th Edition. Illinois: Dryden Press.

Huysamen, G.K. 1983. Psychological Measurement. Pretoria: Academica.

Loubser, M. 1985. Black income and expenditure patterns: 1985 and 2000 . Toespraak gelewer by Black Market
Convention 17 en 18 Julie. Johannesburg: South African Advertising Research Foundation Limited.

Missen, B.J. 1975. The urban African consumer: a study of the buying behaviour of Sowetons in the field of automotive petroleum products. MBA dissertation. Cape Town Graduate School of Business, University of Cape Town.

Marks, A.P. \& Brown, R.J. 1981. A new approach to car ownership forecasting in South Africa. Die Siviele Ingenieur in Suid-Afrika, vol. 23, no. 12.

Nunnally, J.C. 1967. Psychometric theory. New York: McGraw-Hill Book Company.

Robertson, T.S., Zielinski, J. \& Ward, S. 1984. Consumer behavior. Illinois : Scott, Foresman \& Co.

Rousseau, D. 1979. A cross cultural study of automobile perception amongst three student populations. Psychol. Afr., vol. 18.

Rousseau, G. 1981. A study of the product image of cars among black consumers. Humanitas, RSA, vol. 7-1.

Schiffman, L.G. \& Kanuk, L.L. 1983. Consumer behavior. 2nd Edition. New Jersey : Prentice-Hall Inc.

Sentrale Statistiekdiens 1984. Bulletin van Statistieke, vol. 18, no. 3, (September). Pretoria.

Wall, K.A. 1973. Positioning your product in the black market. Advert. Age, June 18. 